\title{
An empirical study on the effect of WTO membership on Iranian Handicraft industry: A case study of Persian carpet
}

\author{
Mansoureh Golmeymi $^{\mathbf{a}^{*}}$, Majid Mirvaisi ${ }^{\mathrm{b}}$, Behnam Maleki ${ }^{\mathrm{c}}$ and Zahra Shirzour Aliabadi ${ }^{\mathrm{d}}$
}

\begin{abstract}
${ }^{a}$ Ferdows Institute of Higher Education, Mashhad, Iran; Armenian State Agrarian University, Yerevan, Armenia
${ }^{b}$ Department of Business Management, Neyshabur Branch, Islamic Azad University, Neyshabur, Iran

${ }^{c}$ Department of Economy, South Tehran Branch, Islamic Azad University, Tehran, Iran

${ }^{d}$ Ferdowsi University of Mashhad, Mashhad, Iran

C H R O N I C L E

Article history:

Received January 16, 2013

Received in revised format

14 April 2013

Accepted 16 April 2013

Available online

April 172013

Keywords:

Global market

Train

Production

International market

Trade

WTO

\section{A B S T R A C T}

The world Trade Organization (WTO) is one of the few organizations, which could significantly influence on foreign trade and consequently on the economic structure of the countries. There are literally different people in Iran who either encourage or discourage WTO membership. Therefore, it is important to analyze Iran's WTO membership to empower Iranian handmade carpet in international trades and to help improvement in quality of production. The purpose of this research is to study the effects of Iran's membership in WTO to empower this industry by performing an empirical survey among 100 experts in this industry. Findings demonstrate that access to WTO plays an important role on increasing production of handmade carpet and developing this industry. In addition, the industry needs to incorporate the recent advances on technology to ensure cost efficient production materials. The industry also needs more creative and innovative ideas due to an increase competition in handmade carpet producers from other countries.
\end{abstract}

\section{Introduction}

World trade organization (WTO) was established in (1947) to facilitate international trade and provide a better framework for people to access better quality and price efficient products and services. There are four objectives associated with WTO including non-discrimination, predictable and growing access to markets, Fair competition and Transparency. WTO is an inter-governmental agency, which serves as a forum for trade negotiations where members draft and sign agreements represented by central government authorities. WTO is also an international court to settle trade disputes among its members, assists developing countries and economies in transition to WTO. The membership of WTO consists of 135 governments, which represent 90 per cent of international trade.

*Corresponding author.

E-mail addresses: golmeymi@gmail.com (M. Golmeymi) 
In addition, there are 30 other countries such as China and Russia, etc., which are in the process of getting accepted and all members are committed to honor agreements (Sierra, 1999). Today, fair trade is considered as a growing global movement and it is a complement for conventional trade, allowing for more equal distribution between under-developed and developed countries (Wielechowski \& Roman, 2012).

During the past two decades, the WTO has steadily come under pressure to incorporate the requirements of free trade in an attempt for guarding non-trade concerns associated with labor, public health and environmental problems or intellectual property rights. As part of the international society's missions to integrate market rules and regulations with non-market values, the WTO has to communicate with other international regimes to deal with behind-the-border measures, which are becoming more and more essential. Nevertheless, there is a narrow line between the consumers' legitimate safeguard, workers or the environment and the unlawful protection of the domestic market against foreign competition. Rules, regulations and standards play essential role since they link the global trade with other international affairs. They can facilitate trade flows by clearly describing product characteristics and improve compatibility. However, they may also constitute non-tariff barriers to trade (NTB) and they could be specified as agreed criteria in which a product performance, its technical and physical characteristics can be evaluated (Gstöhl, 2010).

Emerge to WTO has been a significant event for Iran, which is part of its integration into the global economy. This has led to the lowering of trade barriers and, in turn, has created several opportunities as well as threats for Iranian firms. Opportunities include new markets for exports of goods and services as well as imports of raw materials and technologies, more chances for international business co-operations, etc. However, with a more open market, competition is getting more severe, and business standards such as product quality, safety, etc. are more strictly controlled (Vu, 2008). To survive and to develop in such a competitive business environment, Iranian firms must enhance their competitive positions in the market. To achieve sustainable competitive positions in the market, Iranian firms must incorporate appropriate resources and capabilities. Consequently, they also need to identify good resources and capabilities, which create competitive advantage for Iranian firms.

Among firm capabilities, marketing and innovativeness capabilities are perhaps the most important features for firms in transition economies like Iran. Iran has some advantage for production of handmade carpet and the country has some unique characteristics in this field, which creates an advantage for participating in global competition. Nevertheless, Iranian carpet industry has faced different challenges during the past few years and WTO membership could improve handmade carpet exports (Yaghouti, 2004). In this research, researchers try to consider the effects of Iran's membership to WTO to empower handmade carpet industry.

\section{Material and methods}

In present research, the combined survey research and documentation analysis has been used. In fact, the survey consists of two qualitative and quantitative research techniques and their optimal combination to reach the objectives. The statistical society consists of 100 experts who are involved in exporters of carpets, carpet industrialists, and merchants of carpets. Simple random sampling without replacement has been chosen and each exporter is supposed as a unit of sample. In order to determine the sample size, Krejcie and Morgan sample size table was utilized. The researchers initially performed a qualitative study and then, by the help of a proper questionnaire carried out the quantitative research.

\section{Result and Discussion}

Cronbach's Alpha coefficient was used for estimation the reliability of the questionnaire. Data collection tools included the demographic checklist and a questionnaire made by the researchers. The 
mentioned questionnaire included ten questions ( 5 personal and 5 specialized questions). In addition, 5-degree Likert presented in Table 1 scale was used. After getting the permission to collect the data, the researchers gathered samples by referring to the mentioned location and the questionnaires were filled by them. Besides, for the purpose of documentation, the needed indicators were considered by referring to the books and articles and research exports.

Table 1

Answer individual to questioner questions.

\begin{tabular}{|c|c|c|c|c|c|c|c|c|}
\hline \multirow[b]{2}{*}{ Question No } & \multicolumn{7}{|c|}{ Items } & \multirow{2}{*}{$\begin{array}{l}\text { Standard } \\
\text { Division }\end{array}$} \\
\hline & & $\begin{array}{c}\text { Very } \\
\text { Little } \\
\end{array}$ & Little & Average & Much & $\begin{array}{l}\text { Very } \\
\text { Much }\end{array}$ & Average & \\
\hline \multirow{2}{*}{6} & frequency & 4 & 7 & 8 & 29 & 32 & \multirow{2}{*}{3.97} & \multirow{2}{*}{1.147} \\
\hline & Percentage & 5 & 8.8 & 10 & 36.2 & 40 & & \\
\hline \multirow{2}{*}{7} & frequency & 3 & 4 & 15 & 25 & 33 & \multirow{2}{*}{4.01} & \multirow{2}{*}{1.073} \\
\hline & Percentage & 3.8 & 5 & 18.8 & 31.2 & 41.2 & & \\
\hline \multirow{2}{*}{8} & frequency & 3 & 1 & 12 & 27 & 37 & \multirow{2}{*}{4.17} & \multirow{2}{*}{0.990} \\
\hline & Percentage & 3.8 & 1.3 & 15 & 33.8 & 46.3 & & \\
\hline \multirow{2}{*}{9} & frequency & 3 & 5 & 11 & 28 & 33 & \multirow{2}{*}{4.03} & \multirow{2}{*}{1.072} \\
\hline & Percentage & 3.8 & 6.2 & 13.8 & 35 & 41.2 & & \\
\hline \multirow{2}{*}{10} & frequency & 3 & 4 & 6 & 29 & 38 & \multirow{2}{*}{4.18} & \multirow{2}{*}{1.032} \\
\hline & Percentage & 3.8 & 5 & 7.5 & 36.2 & 47.5 & & \\
\hline
\end{tabular}

To determine the sample measure, the researcher has used the following,

$$
n=\frac{N \times z_{\alpha / 2}^{2} \times p \times q}{\varepsilon^{2} \times(N-1)+z_{\alpha / 2}^{2} \times p \times q},
$$

where $N$ is the population size, $p=1-q$ represents the yes/no categories, $z_{\alpha / 2}$ is CDF of normal distribution and finally $\varepsilon$ is the error term. Since we have $p=0.5, z_{\alpha / 2}=1.96$ and $N=100$, the number of sample size is calculated as $n=80$.

\section{Research Variables}

The research is an exploratory (survey) one; therefore, its variables are:

Dependent variables: the result of Iran's joining to WTO

Independent variable: Increase of scientific and professional power in the field of production of handmade carpet

Independent variable: Iran's membership in WTO

Adjustment variable: age, gender, education level, country of activity

In this survey Cronbach Alpha (Cronbach, 1951) has been calculated as 0.9301, which is well above the minimum acceptable level of 0.70.Therefore alpha coefficient have confirmed for the internal validity. Since the variables under investigation are interval ones, Kolomogrov - Smirnov's test is suggested as the best one for determining the variable normality and the results are summarized in Table 2. The following states the hypothesis of this survey.

$H_{0}$ : The variable is in normal distribution

$H_{1}$ : The variable is not in normal distribution 
Table 2

Smirnov Klomogrove's test for the results of Iran's membership in WTO

\begin{tabular}{lccccr}
\hline \multicolumn{1}{c}{ Variables } & Average & $\begin{array}{c}\text { Standard } \\
\text { deviation }\end{array}$ & $\begin{array}{c}\text { Smirnov } \\
\text { Klomogrove'sZ } \\
\text { index }\end{array}$ & $\begin{array}{c}\text { Significance } \\
\text { level }\end{array}$ & Result \\
\hline $\begin{array}{l}\text { Increase of scientific \& } \\
\text { professional power }\end{array}$ & 4.07 & 0.941 & 1.462 & 0.028 & Not normal \\
\hline
\end{tabular}

If the significance of test is less than 0.05 we can say that the variable under examination is not normal, otherwise the distribution of the variable is accepted as normal.

Iran's membership in WTO effects on Increase of scientific and professional power in the field of production of handmade carpet

Based on the results of Table 2, we can conclude that the distribution of the variable is not normal so non-parametric one sample sign test will be used to test the hypothesis. If we assume that:

M: Middle variable of hypothesis Iran's membership in WTO effects on decrease cost price of handmade carpet, in investigated community

Less quantity or equal 3 as a no effective and more than 3 as an effective factor, thus we should test following assumptions:

$\left\{\begin{array}{l}H_{0}: M \leq 3 \\ H_{1}: M>3\end{array}\right.$

Hypothesis test of zero $\left(\mathrm{H}_{0}\right)$ against Hypothesis of one $\left(\mathrm{H}_{1}\right)$ is as follows:

If and only if $\mathrm{P}$-value $<0.05$ then $\mathrm{H}_{0}$ is rejected and $\mathrm{H}_{1}$ is accepted.

Table 3

Sign test for Variable of Iran's membership in WTO effects on Increase of scientific and professional power in the field of production of handmade carpet

\begin{tabular}{ccccc}
\hline Median in sample & $\begin{array}{c}\text { Number less than the } \\
\text { median }\end{array}$ & $\begin{array}{c}\text { Number equal whit } \\
\text { median }\end{array}$ & $\begin{array}{c}\text { Number more than } \\
\text { median }\end{array}$ & Significance test \\
\hline 4.2 & 7 & 5 & 68 & 0.028 \\
\hline
\end{tabular}

As we consider from the results of Table 3, the significance is equal $0.028<\alpha=0.05$ and hypothesis of $\mathrm{H}_{0}$ can be rejected and $\mathrm{H}_{1}$ is accepted. It is means Iran's membership in WTO influences on increase of scientific and professional's power in the field of production of handmade carpet.

This means that there are differences between the current situation and the desired situation. During the past few years, there has been tremendous increase on market development.

Because of new technology combined with an increase on workforce's training, different labor market from the $20^{\text {th }}$ century has been created. Therefore, after joining WTO, organizations need to be empowered to face with possible challenges by empowering their employees and there is a primary question associated with the proposed study of this paper as follows,

\section{1- $\quad$ Is the level of load factor resulted by Iran's membership in the WTO meaningful?}

We should use from the method of analyze of load factor for this mean and find load factor of Iran's membership in the WTO. If these loads are more than 0.5, we make a conclusion that the level of load factor by Iran's membership in the WTO is meaningful. If we assume that:

$X_{1}$ : Increase of scientific and professional power in the field of production (dependent)

Y: Iran's membership in the World Trade Organization (independent) 
The results of the load factor test quantity of index KMO is equal of 0.845 ; hence, the load factor by these data is desirable or useful and the results are summarized in Table 4 as follows,

\section{Table 4}

The level of load factor resulted by Iran's membership in the World Trade Organization (WTO) Head of questions Increase of scientific and professional power in the field of production Level of load Factor

Based on the result of Table 4, the load factor is in a desirable level; hence, the level of load factor resulted by Iran's membership in the World Trade Organization is meaningful.

\section{2- $\quad$ Are there meaningful different between the idea men and women' exporters about research' variables?}

\section{Table 5}

The result of descriptive indexes of the idea men and women about research's variables in two group of men and women

\begin{tabular}{lcc}
\hline Variables mean $\pm s d$ & Men & Women \\
\hline $\begin{array}{l}\text { Increase of scientific and professional } \\
\text { power in the field of production }\end{array}$ & $0.090 \pm 4 / 14$ & $0.800 \pm 3$ \\
\hline
\end{tabular}

Based on the result of Table 5, there is no difference between the male and female Exporters (Respondents). This means that women in Iran with the man can act powerfully and they would be able to become successful in business and commerce and gender is not the reason for success or failure but the ability of other people can lead to success or failure.

\section{Are there meaningful relate between the idea men and women' exporters about research' variables and level of educational?}

Let $\mathrm{Y}$ be the variable of experts' idea about research' variable and $\mathrm{X}$ be the level of educational variable. Therefore, we have,

\section{Table 6}

The result of Spearman coefficient of correlation test for study relate between two variables experts' idea about research' variables and level of educational

\begin{tabular}{lccc}
\hline \multirow{2}{*}{ Variable } & \multicolumn{2}{c}{ Level of educational } & \multirow{2}{*}{ Result } \\
\cline { 2 - 3 } $\begin{array}{l}\text { Increase of scientific and professional power in the field of } \\
\text { production }\end{array}$ & -0.139 & 0.22 & $\begin{array}{c}\text { Not } \\
\text { confirmed }\end{array}$ \\
\hline
\end{tabular}

Based on the results of Table 6, there is no correlation between the man and woman's experts' feedbacks about research's variables and educational backgrounds. As a result, education is not the only reason for success. The research variables and education does not lead to any relation on significance level. The researchers draw attention to the equality of the performance of younger welleducated ones with more experienced people, as regards ineffectiveness of education. Therefore, long and good experience in business can be an alternative for education and people who have more experience, less education, and younger people have higher education.

4: Are there meaningful relate between the idea men and women's exporters about research' variables and age?

Let $X$ represent age and $Y$ be experts' feedback and Table 7 shows the results of Spearman coefficient correlation between these two variables. 


\section{Table 7}

The result of Spearman coefficient of correlation test for study relate between two variables experts' idea about research' variables and age

\begin{tabular}{|c|c|c|c|}
\hline \multirow{2}{*}{ Variable } & \multicolumn{2}{|c|}{ Age } & \multirow[b]{2}{*}{ Result } \\
\hline & Spearman ratio & Significance & \\
\hline $\begin{array}{l}\text { Increase of scientific and professional power in the field of } \\
\text { production }\end{array}$ & -0.145 & 0.199 & $\begin{array}{c}\text { Not } \\
\text { confirmed }\end{array}$ \\
\hline
\end{tabular}

Based on the results of Table 7, there are not any relationship between idea of man and woman's experts about research's variables and age. The upper or lower age is not the criteria for success or failure in the production and trade of carpets. The research variable and age does not lead to any relationship based on the significance level. The researchers draw attention to the equality of the performance of younger well-educated ones with more experienced people, as regards ineffectiveness of age. Therefore, individuals with higher education performed the same as older and more experience ones.

\section{Conclusion}

In this survey, we have performed an empirical investigation on measuring the effect of WTO membership on Persian carpet export. The proposed study of this paper has designed a questionnaire a Likert scale and distributed among 100 experts. The results of the survey have confirmed that WTO membership could significantly contribute to export of this industry. However, people who are involved in production, logistic and export of this kind of product must be empowered, significantly to cope with recent advances on technology. In today's complex world of creativity and innovation, all organizations must be able to compete with existing competitors or new arrivals. Therefore, the success of globalization requires specialized training for everyone, constantly. Governments need to develop international markets of carpet and related organizations need to have beneficial cooperation. The government and responsible organizations should step forward in necessary efforts to increase expertise in this industry.

\section{References}

Almasi, H. Kashani, FH. Saeedi, N. Pazvari, MH. \& Hosseini, Z. (2010). Studying the effect of knowledge management on e-commerce. $1^{\text {st }}$ conference on e-commerce. Booshehr Islamic Azad University Iran.

Cronbach, L. J. (1951). Coefficient alpha and the internal structure of tests. Psychometrika, 16(3), 297-334.

Gstöhl, S. (2010). Blurring regime boundaries: uneven legalization of non-trade concerns in the WTO. Journal of International Trade Law and Policy, 9(3), 275-296.

Hamada, T. (2004). Iran's accession to WTO, 2-4.

Hosseini, S.Y, Kashani, FH, \& Saeedi, N. (2010). Designing a model for Iran's carpet industry compatibility in trend of joining to World Trade Organization. $4^{\text {th }}$ international conference on strategic management. Tehran. Iran.

Sierra, E. (1999). The quality-related international trade agreements of the World Trade Organization and their implications for quality professionals, The TQM Magazine, 11(6), 396-401.

$\mathrm{Vu}, \mathrm{T} . \mathrm{A}$. (2008). Challenges to be overcome by Vietnam after one year of WTO member, Economic Development Review, 17, 19-21.

Wielechowski, M. \& Roman, M. (2012). The Essence of fair trade and its importance in the world economy. Oeconomia, 11(4), 47-57

Yaghouti, R. (2004). Influence of world Trade Organization on export of handmade carpet. Ferdusi University, Mashhad. 